\title{
Semi-winged pests of cultural plants in Fergana, Uzbekistan
}

\author{
Alevtina Kozhevnikova ${ }^{1, *}$ \\ ${ }^{1}$ Tashkent State Agrarian University, University str., 2, Tashkent province, 100140, Uzbekistan
}

\begin{abstract}
In cultivated landscapes, the negative influence of herbivorous species of bugs on agricultural plants is especially affected. They are distinguished by a wide variety in species composition and in the number of individual species. Some of them can multiply in large numbers. Research is of theoretical and practical importance, since many species are pests of agricultural crops, some species carry viral plant diseases. The nature of the harm caused by various types of herbivorous bugs was studied, since bugs, when feeding on their piercing-sucking mouth apparatus, pierce plants and feed on plant sap. It has been established that the damage caused to plants by bedbugs affects the abscission of fruit elements and the timing of the developmental phases from egg to imago depends on temperature and humidity.
\end{abstract}

\section{Introduction}

Harvest losses of the world's most important agricultural crops caused by pests range from 20 to $80 \%$, this is a well-known fact. Currently, in protecting plants from pests in an integrated system, more and more attention is paid to progressive methods of protecting crops, this includes the biological method $[1,2,5]$. The basis of the biological method is the study, first of all, of the species composition of pests, the number, harmfulness, the nature of the harm they cause, the identification of food links, biological and ecological characteristics of the relationship between harmful and beneficial species, then, on this basis, the development of biological control measures [3]. Many researchers note that in recent years there has been an expansion of habitats and an increase in the harmfulness of various pests, such as herbivorous bugs, cicadas, whiteflies and other insects. The main pests from the order of hemipteran (Hemiptera), belong to the family of horseflies (Miridae) [3-5]. Among the hemiptera, the Miridae family occupies a special place; it is ecologically associated with various biotopes and plays an important role in agrobiocenoses. Most of the species of this family, being phytophages, are serious pests of cotton, forage grasses, vegetables, medicinal plants, and tree and shrub species [6-8]. As a result of feeding bugs, the condition and further development of plants are disturbed, accompanied by various deformations and death of individual parts of the plants. An example of this is the destruction of the generative organs of cotton by a field bug: buds, flowers, ovaries, and bolls [8-12].

\footnotetext{
* Corresponding author: a.kozhevnikova@yandex.com
} 
In addition, A. Kuchkarov revealed that the saliva secretion of the field bug causes lysis of plant tissue, impaired metabolism and membrane permeability, which may underlie the biologically damaging effect of bugs on agricultural plants. The aforementioned author also notes that there are phyto-zoophages and zoo-phytophages among the half-winged Mirati bugs that regulate the number of agricultural pests [4-7]. The fauna of hemiptera insects (Hemiptera) is represented by sucking insects, which, with their complex and peculiar biology and ecology, show high specialization and adaptation to external habitat conditions. The degree of their knowledge is not yet sufficient to assess the importance of harmful species $[8,9]$.

When cultivating new agricultural crops, it is necessary to take into account the emergence of new pests, the study of their species composition, developmental features, distribution, their natural enemies, in order to develop modern innovative approaches to protecting plants from harmful organisms. According to many scientists, many species of herbivorous bugs are serious pests of agricultural crops [10-18]. In addition, a characteristic dependence of the damageability of cotton and other cultivated plants on the phase of plant development is noted. Researchers believe that the increase in the harmfulness of herbivorous bugs occurs during the period of reduction of the compensatory characteristics of plants. Some species of herbivorous bugs carry dangerous viral plant diseases. At present, the attention of researchers is directed to the need to develop progressive methods of plant protection against harmful Hemipterans [17].

Entomological research in various regions of the country is ongoing. However, the harmful effects of bedbugs on biocenotic processes in the Fergana Valley have not yet been sufficiently studied. The purpose of our studies of this group of insects in the Fergana Valley is aimed at studying the species composition of bugs, pests of cultivated plants in the Fergana Valley, their harmfulness, biological, ecological characteristics, dynamics of development and numbers, as well as the impact of Hemiptera on biocenotic processes.

\section{Materials and methods}

The material for this work was 20 years of research carried out in the Fergana Valley of Uzbekistan (Andijan and Fergana regions). We used the methods generally accepted in entomology and special methods by G.K. Dubovsky [2, 4]. Stationary and route gatherings, observations, experiments and counts were carried out.

The Fergana Valley is located in the eastern part of Uzbekistan and is characterized by a large amount of heat and a long growing season in the summer, providing the cultivation of many heat-loving plants. In the conditions of artificial irrigation, favorable conditions are created for the growing season of such heat-loving plants as cotton and others [2].

In the system of the Tien Shan and Pamir-Alai ranges, the Fergana Valley is a deep depression located between the mountains. All the variety of natural conditions typical of Central Asia is represented in the Fergana Valley. There are four main zones: central, adyr, and foothill and alpine $[2,7,9]$.

The alpine zone is represented by powerful ridges framing the Fergana Valley. The foothill zone is well expressed in the lower strip of the mountains that form the Fergana Basin. The adyr zone is located between the central lowland part and the foothills of the Fergana Valley. In the central part of the Fergana Valley, the main areas of cultivated land are concentrated, on which cotton, cereals and other agricultural plants are cultivated. In addition, large areas of orchards and vineyards are concentrated here [4-6].

The climate of the Fergana Valley is continental. Protection of plants from pests and diseases, according to experts, from an economic point of view, is much more effective than eliminating the consequences of full-scale emergencies related to plant health. It is 
often very difficult, and sometimes impossible, to eradicate pests and plant diseases after they have settled. It takes a lot of time and money to fight them [2].

Hemiptera were harvested using a standard entomological net mowing technique. The unit of account was taken to be 100 sweeps of the net. The collection of insects was carried out with an ordinary entomological net and a net with removable bags. The collected hemiptera from the net spilled out into a coarse calico bag, which was tied and placed in a closed plastic bag, where there was a cotton swab soaked in ether.

Insects frozen in this way in a plastic bag were delivered to the laboratory, where entomological processing of the samples was carried out. In some cases, the collection of bugs, for example, when studying feeding relationships, was carried out manually using a test tube. With high-quality collections, the sampling of bugs from the net was carried out using a simple device made by us, (see in Fig. 1). This device consists of an ordinary test tube and a glass tube of the same diameter and length, with a test tube. The test tube and the tube are connected by a rubber tube $5-8 \mathrm{~cm}$ long. The rubber tube makes it possible to fold the glass parts parallel to each other, and, at the bend, the rubber flattens and thereby prevents insects from passing from the glass tube to the test tube and vice versa.

When removing insects from the net, the device is in the folded position. As soon as the tube is filled with insects, the device is straightened up with the test tube and the insects pass into the test tube through the rubber tube. Then the device is folded and they continue to select bugs from the net into a glass tube, as it fills, the insects are again transferred to the test tube.

This process is repeated until the tube is sufficiently full. For long-term use, it is useful to put pieces of filter paper in the test tube, which will prevent the increase in humidity and the adhesion of insects to the walls of the test tube.

To establish the number of hemiptera on agricultural plants during the growing season, regular mowing was carried out every 10 days on crops and on wild vegetation in their environment.

Collecting bugs was also carried out on trees and shrubs. When studying the biology of certain species, they used cages, canopies and gauze insulators.

We also used this method when raising larvae in order to breed adults, for an accurate diagnosis of the species. To identify the wintering phases of some species, the stubble and the remaining stems of alfalfa and weeds were cut in early spring, after which the stems were cut longitudinally and examined. In addition, plots surrounded by crop fields, in gardens and along roads with wild vegetation were surveyed in early spring and autumn.

To establish the period of oviposition, systematic dissections of females were performed, which were collected in nature. By the beginning of the formation and maturation of eggs, one can judge the beginning of oviposition in nature, and a decrease in the number or absence of eggs in the females being opened may indicate the end of oviposition. In parallel, egg-laying observations were carried out in cages. In addition, the collection of bugs was carried out by examining the upper soil layer under the plants.

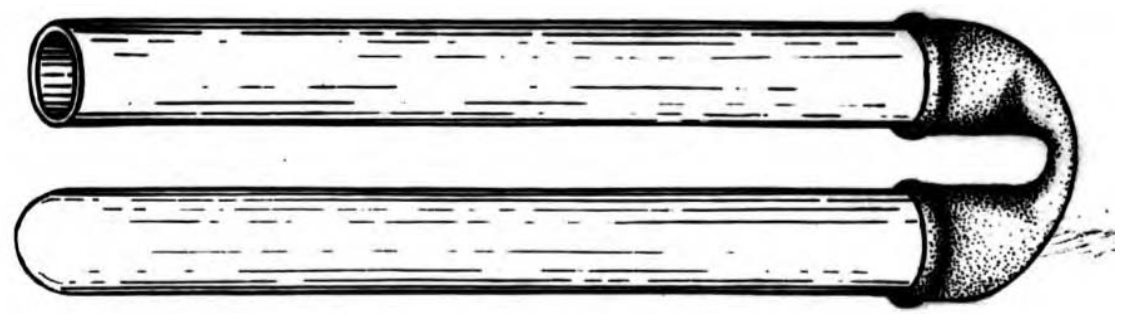

Fig. 1. Device for sampling insects from a net. 


\section{Results and discussion}

An integrated plant protection method is a combination of methods for protecting plants from pests, diseases and weeds, while creating differentiated systems of protective measures. It allows you to preserve beneficial arthropods, reduce the consumption of pesticides and preserve the harvest.

This ecosystem approach combines a variety of control methods to grow healthy plants with minimal or no pesticides. Harmful organisms pose a constant threat to plants. The impact of harmful organisms affects the quality of crop production. Key elements of integrated plant protection include a pest surveillance system and the use of natural pest regulation mechanisms.

Effective integrated plant protection includes the integration of a biological method with other methods, in the general system of protective measures. The control of plant pests must be rational, economic, and effective and must prevent pollution of the environment and food, i.e. ensure the application of the safest system of pest control of agricultural crops, built on a selective approach.

In this regard, the main directions and tasks of our research in the field of integrated plant protection were the development of methods for express diagnostics of pests, the development of natural resources of entomophages, the development of new biological plant protection products based on the study of entomophages.

Research in the development of methods for express diagnostics of pests, we carried out with a wide selection of sucking pests, in particular, various types of bugs, the study of which is currently of theoretical and practical importance.

The harm caused by herbivorous bugs is manifested mainly in the following directions. Herbivorous bugs, when feeding on their piercing-sucking mouth apparatus, pierce plants and feed on plant sap. When feeding on cotton, dark spots are visible on the fruit elements. Damage caused to plants by bedbugs affects the shedding of fruit elements.

According to our information, in the cotton agrobiocenosis of the Andijan and Fergana regions, we identified 8 species of Mira bugs, from the genus Adelphocoris - Adelphocoris lineolatus, Adelphocoris jakovlevi; from the genus Lygus - Lygus pratensis, Lygus rugulipennis, Lygus gemellatus; from the genus Campylomma - Campylomma diversicornis, Campylomma verbasci; from the genus Camptobrochis - Camptobrochis punctulatus.

As a result of studying the dynamics of bedbug numbers, it was noted that on cotton, alfalfa and other crops, an increase in the number of adults and bedbug larvae coincides with the period of formation of generative organs. Their high abundance was observed in the second decade of August. The maximum number of bed bugs was observed on seed alfalfa, since pests have accumulated on it for a number of years.

The most harmful species is the alfalfa bug, Adelphocoris lineolatus Goeze. This species was first described in 1778. The species is known as a pest of seed alfalfa throughout the Fergana Valley. The harmfulness of Adelphocoris lineolatus is that it sucks juices from plants and their generative organs, as a result of which they fall off. Damage to young alfalfa plants is especially dangerous. The harmfulness of Adelphocoris lineolatus on cotton consists in the loss of fruit elements. Buds, flowers, ovaries and capsules fall off. In the place where the cotton boll is punctured, a tumor growth appears on its inner side, which turns into a brown substance in which microorganisms are found.

The study of the three stages of development of bedbugs showed that the time of passage from egg to imago depends on temperature and humidity. 
Table 1. Taxonomic analysis of the bugs fauna of the Fergana Valley (2009-2019).

\begin{tabular}{|c|c|c|}
\hline Family & Number of births & Number of species \\
\hline Nepidae & 3 & 3 \\
\hline Naucoridae & 1 & 1 \\
\hline Notonectidae & 1 & 1 \\
\hline Saldidae & 1 & \\
\hline Geridae & 1 & 1 \\
\hline Corixidae & 1 & 1 \\
\hline Leptopodidae & 2 & 2 \\
\hline Tingidae & 4 & 8 \\
\hline Miridae & 29 & 50 \\
\hline Nabidae & 1 & 3 \\
\hline Anthocoridae & 2 & 3 \\
\hline Cimicidae & 1 & 1 \\
\hline Reduviidae & 4 & 8 \\
\hline Berytidae & 2 & 4 \\
\hline Lygaeidae & 27 & 40 \\
\hline Pyrrhocoridae & 2 & 3 \\
\hline Stenocephalidae & 1 & 2 \\
\hline Coreidae & 10 & 11 \\
\hline Rhopalidae & 6 & 12 \\
\hline Acanthosomatidae & 2 & 4 \\
\hline Cydnidae & 3 & 4 \\
\hline Scutelleridae & 3 & 4 \\
\hline Pentatomidae & 26 & 49 \\
\hline
\end{tabular}

As can be seen from Table 1, the taxonomic analysis of the Hemiptera fauna of the Fergana Valley (Andijan and Fergana regions) showed a rather extensive list of the main families and species. 
Table 2. Merida bugs in the cotton-alfalfa biocenosis of the Fergana Valley (2009-2019).

\begin{tabular}{|c|c|c|}
\hline Species & Cotton & Alfalfa \\
\hline Adelphocoris lineolatus & +++ & +++ \\
\hline Adelphocoris jakovlevi & + & ++ \\
\hline Lygus pratensis & +++ & +++ \\
\hline Lygus gemellatus & +++ & ++ \\
\hline Lygus rugulipennis & ++ & ++ \\
\hline Campylomma verbasci & ++ & ++ \\
\hline Campylomma diversicornis & ++ & ++ \\
\hline Camptobrochis punctulatus & ++ & ++ \\
\hline Other types & + & + \\
\hline
\end{tabular}

Note: +++ - mass species, ++ - common species, + - rare species

Table 2 shows that Adelphocoris lineolatus, Lygus pratensis and Lygus gemellatus are the predominant and widespread species in the Fergana Valley.

\section{Conclusions}

To suppress the number of bugs and develop the foundations of protective measures carried out in the Fergana Valley, it is necessary to determine the species composition of bugs of pests of cultivated plants, their express diagnostics, study of harmfulness, biological, ecological characteristics, dynamics of development and number, as well as the impact of hemiptera on biocenotic processes in specific regions.

The study of the entomophages of the dominant species of herbivorous bugs has shown that they are destroyed by many predatory and parasitic animals.

Bedbugs, like other insects, are attacked by natural enemies, which play a role in reducing their numbers.

To ensure the effectiveness of the protective measures carried out, it is recommended to use natural populations of natural entomophages.

Some species of herbivorous bugs are zoophages, along with feeding on animal food, they feed on plant sap.

Integrated crop protection ensures nature protection, sustainable agricultural production and contributes to human and animal health.

\section{References}

1. N. Teshaev, B. Mamadaliyev, A. Ibragimov, S. Khasanov, InterCarto. InterGIS, 26(3), 324-333 (2020)

2. B. S. Boltaev, A. G. Kozhevnikova, SH. A. Makhmudova, M. M. Ablazova, Science, production, business: the current state and ways of innovative development of the agricultural sector on the example of the Baiserke-Agro Agroholding, 2, 219 (2019)

3. A. Jumanov, S. Khasanov, A. Tabayev, G. Goziev, U. Uzbekov, E. Malikov, IOP Conf. Ser.: Earth Environ. Sci., 614(1), 012150 (2020)

4. R. Kulmatov, A. Taylakov, S. Khasanov, Environ. Sci. Pollut. Res., 28(10), 1224512255 (2021)

5. A. G. Kozhevnikova, Actual problems of science, 84-87 (2019)

6. I. Aslanov, S. Khasanov, Y. Khudaybergenov, M. Groll, Ch. Opp, F. Li, E. Ramirez Del-Valle, E3S Web Conf., 227, 02005 (2021) 
7. S. Isaev, S. Khasanov, Y. Ashirov, T. Karabaeva, A. Gofirov, E3S Web Conf., 244, 02012 (2021)

8. N. N. Muminov, SH. A. Umarov, A. P. Kononenko, J. Plant protection, 2, 42 (1981)

9. S. Isaev, S. Khasanov, Y. Ashirov, A. Gofirov, T. Karabaeva, E3S Web Conf., 244, 02047 (2021)

10. Y. Peng, F. Li, N. Xu, R. Kulmatov, K. Gao, G. Wang, Y. Zhang, Y. Qiao, Y. Li, H. Yang, S. Hao, Q. Li, S. Khasanov, Chinese Journal of Eco-Agriculture, 29(2), 312-324 (2021)

11. A. SH. Khamraev, A. S. Baltabaev, Modern zoological science and scientificmethodological problems of its teaching, 64 (1993)

12. S. Isaev, I. Begmatov, G. Goziev, S. Khasanov, IOP Conf. Ser.: Mater. Sci. and Eng., 883(1), 012080 (2020)

13. N. Sabitova, O. Ruzikulova, I. Aslanov, E3S Web Conf., 227, 03003 (2021)

14. B. Sh. Matyakubov, Z. J. Mamatkulov, R. K. Oymatov, U. N. Komilov, G. E. Eshchanova, InterCarto, InterGIS, 26, 229-239 (2020)

15. N. Ch. Namozov, D. A. Kodirova, M. I. Usmonova, International journal of scientific \& technology research, 9(03), 5491-5493 (2020)

16. I. Musaev, A. Bokiev, M. Botirova, E3S Web Conf., 227, 05004 (2021)

17. Beingolea O, Anfonae Estos Agreculture, 160 (2015)

18. A. Babajanov, R. Abdiramanov, I. Abdurahmanov, U. Islomov, E3S Web Conf., 227, 05001 (2021) 